\title{
Anna Grześkowiak-Krwawicz, Czy rewolucja może być legalna? 3 maja 1791 w oczach współczesnych, Wyd. DiG, Warszawa 2012, 226 stron
}

Autorki znawcom okresu przedstawiać nie trzeba: wszak to Uczona należąca do wąskiej grupy najwybitniejszych wszechczasów polskich znawców epoki Oświecenia. Historykom prawa nader bliska podejmowanymi tematami. Tak jest i teraz, co rzuca się w oczy samym tytułem kolejnej książki Anny Grześkowiak-Krwawicz.

Autorka bardzo dobrze zdaje sobie sprawę z szokującego charakteru pytania postawionego w tytule książki, o czym z wdziękiem pisze w pierwszych zdaniach wstępu. $\mathrm{W}$ tym miejscu też poszerza zdumiewające pytanie z tytułu dzieła o drugie: czy 3 maja 1791 r. był rewolucją? Na wstępie też zderza nasze dzisiejsze wyobrażenia prawne z tym sprzed ponad dwustu lat, konstatując, że o ile dzisiejszy czytelnik na oba pytania odpowie negatywnie, o tyle uczestnik wydarzeń przed z górą dwoma wiekami na oba odpowiadał twierdząco. Anna Grześkowiak-Krwawicz przyjmuje w książce perspektywę ludzi tamtej epoki, czyli przenosi nas w czasy Ustawy Rządowej. A pytanie zawarte w tytule nasunęła A. Grześkowiak-Krwawicz wypowiedź na sesji sejmowej 9 maja 1791 r. posła wileńskiego, Tadeusza Korsaka, który wniósł, „aby napisać prawo wszelkich odtąd rewolucji zakazujące” (s. 11). Trafnie Autorka wskazuje, że dowodzi to zarówno wiary w siłę prawa, którym można rewolucji zapobiec, można ją prawem powstrzymać, jak też świadczy o specyficznym pojmowaniu wydarzenia określanego mianem rewolucji.

Warto może przypomnieć znany fakt, że samo słowo rewolucja przeszło w historii pojęć ewolucję: od nauk ścisłych, gdzie niegdyś oznaczało ruch niedający się zatrzymać (De revolutionibus orbium coelestium pewnego astronoma z Torunia), po „nie, Panie, to nie rewolta, to rewolucja” - co usłyszał Ludwik XVI w noc 14/15 lipca 1789 r. od księcia de la Rochefoucauld-Liancourta, a co akcentowało nieodpartość ruchu, niemożność jego powstrzymania. Między jednym a drugim rozumieniem jest kilkaset lat i wiele niuansów tego słowa. To od czasu rewolucji francuskiej i rewolucji amerykańskiej poczynając mamy do czynienia z refleksją teoretyczną, pozwalającą odróżniać zmiany ekip rządzących od rewolucji naznaczonej patosem nowości i wolności. Dalsza ewolucja - w wieku dziewiętnastym - pojęcie nieodpartego ruchu przekształci w ideę konieczności historycznej ${ }^{1}$.

Polska czasów Sejmu Wielkiego jest gdzieś przed końcem osiemnastowiecznej ewolucji i m.in. to nam pokazuje A. Grześkowiak-Krwawicz w swojej książce. Rewolucja „mogła oznaczać zmianę w składzie rządu, reformę systemu władzy (również pokojową), zamach stanu, powstanie narodowe, wystąpienie poddanych przeciw władzy państwowej (choć to zwano również buntem), wystąpienie jednego stanu w obronie swoich praw przeciw innym stanom (to już pod wpływem rewolucji francuskiej), wreszcie jakiekolwiek rozruchy czy wykroczenia przeciw przyjętej praktyce politycznej” (s. 13) - porządkuje stan wiedzy Autorka. Strony politycznego sporu o Ustawę Rządowa zga-

1 H. Arendt, O rewolucji, przekł. M. Godyń, Kraków 1991, s. 47; J. Baszkiewicz, Wolność, równość, własność. Rewolucje burżuazyjne, Warszawa 1981, s. 6. 
dzały się przynajmniej w jednym: „coś w tym dniu zburzono, a na tym miejscu powstało coś nowego" (s. 16). Wydarzenie było nagłe, gwałtowne, zaskakujące, radykalnie zmieniające sytuację w kraju - to były cechy ówczesnego rozumienia rewolucji, jak wywiodła A. Grześkowiak-Krwawicz. Sam marszałek Małachowski ogłosił „rewolucję w rządzie", a więc słowo rewolucja odnosił do zmian w rządzie, ale akcentował przy tym tryb nadzwyczajny postępowania: to nie jest sejm, ale rewolucja (s. 17, 21). Autorka wywiodła, że używane określenie ustawa rewolucyjna malkontenci odnosili głównie do metod jej ustanowienia, zaś zwolennicy ustawy majowej - do jej skutków; trafnie zauważa jednak Autorka, iż tym samym nie tylko wydarzenia, ale i samo prawo utożsamiano $\mathrm{z}$ rewolucją.

Anna Grześkowiak-Krwawicz czyni ciekawe spostrzeżenie, iż „termin rewolucja sam w sobie nie zawierał elementów wartościujących, choć można go było różnie interpretować” (s. 30). Było jednak dla przeciwników oczywiste, że skuteczne przeprowadzenie tak dużej rewolucji musiało być wynikiem spisku, a to pojęcie już miało pejoratywne znaczenie. Tym bardziej, że mówiono o „spisku na wolność” (s. 63). Szlachecki naród w szlacheckiej Rzeczypospolitej wolność cenił sobie od wieków najwyżej. Europejskie Oświecenie też postawiło ją na piedestale. Kiedy latem 1789 r. deputowani francuskiego Zgromadzenia Narodowego z zapałem układali katalog owego kodeksu naturalnego, jakim miała się stać Deklaracja praw człowieka i obywatela, na pierwszym miejscu umieścili stwierdzenie o wolności i równości: „Ludzie rodzą się i pozostają wolni i równi z punktu widzenia prawa”. Nie było ani nic dziwnego, ani nic oryginalnego, że te właśnie idee ujęli jako wybijające się na czoło „naturalnych, świętych i niepozbywalnych” praw człowieka. Przecież od czasów Grocjusza wolność zgodnie była akcentowana przez filozofów jako naturalne prawo człowieka, ze stanu naturalnego, sprzed umowy społecznej jeszcze się wywodzące. Szeroko pojmowana wolność była tym najbardziej pożądanym do zrealizowania prawem naturalnym, bo miała oznaczać zrzucenie pęt feudalnych, miała przynieść różnicę odczuwalną zaraz. Nie przypadek to, że Jan Jakub Rousseau zacznie swoje dzieło słowami: „Człowiek urodził się wolny, a wszędzie jest w okowach. (...) Jak się dokonała ta zmiana?” i złoży obietnicę wyjaśnienia, co mogłoby tę zmianę "uprawomocnić” (Umowa społeczna). W odniesieniu do Ustawy Rządowej A. Grześkowiak-Krwawicz konkluduje, że dyskusja „toczyła się zarówno wokół sposobu jej ustanowienia, jak i wokół jej treści. Jej sens można by zawrzeć w jednym słowie - wolność" (s. 102).

Amerykański historyk na pytanie, czym była rewolucja, odpowiedział, że była wielkim projektem. Była projektem uszczęśliwienia społeczeństwa, przetarcia ścieżek prowadzących ku temu szczęściu, podzieleniem się dobrodziejstwami wolności, równości i braterstwa. Była projektem pięknym, lecz naiwnym². Rewolucja miała uszczęśliwić ludzi, ale Robespierre mawiał, że rewolucji nie robi się z kodeksem w ręku³; świetnie to realizował. Stulecie XVIII - Wiek Światła i Rozumu - były to czasy, gdy filozofów przenikał entuzjazm przekształcania świata, zaprowadzania w nim ładu, doskonalenia go, bo też chyba po raz pierwszy w dziejach ludzkości zapanowała powszechna wiara w twórczy rozum, zdolny dokonać zmiany rzeczywistości.

2 C. L. Becker, Państwo Boże osiemnastowiecznych filozofów, przekł. J. Ruszkowski, Poznań 1995, s. 35 .

3 J. Baszkiewicz, op. cit., s. 22. 
Podstawowym narzędziem tej mocy twórczej miało być - to oczywiste dla ówczesnych - prawo, prawo zgodne z prawami naturalnymi człowieka, wsparte na czymś w rodzaju kodeksu naturalnego. Nie przewidywano szczególnych trudności przy ustaleniu treści owych praw naturalnych, bo służyć miał ku temu niezawodny rozum, były one racjonalne (tak chętnie próbowano stawiać znak równania między „naturalnym” a „racjonalnym”), zaś język rozumu jest językiem samego Boga - wyjaśniał J. J. Burlamarqui, wywodząc, że „przez Prawo natury rozumie się Prawo, które Bóg narzuca wszystkim ludziom i które mogą oni odkryć i poznać, kierując się samym tylko światłem rozumu” ${ }^{4}$. Bóg nie pojawiał się u wszystkich mędrców epoki, chociaż obecny był u wielu, ale już nie jako twórca średniowiecznego prawa boskiego, lecz jako twórca natury rzeczy, a więc dawne prawo boskie zastępowane było przez prawo naturalne. Montesquieu napisze w Duchu praw: „Prawo na ogół jest to rozum ludzki, ile że włada wszystkimi ludami ziemi; prawa zaś polityczne i cywilne każdego narodu winny być jedynie szczególnymi wypadkami, w których objawia się ten rozum ludzki" ${ }^{5}$, co dosłownie przepisze wkrótce we francuskiej Wielkiej Encyklopedii. Oświeceni filozofowie zajęci byli obmyślaniem projektów zmierzających do uszczęśliwienia świata, ludzkości. Rządy rozumu miały przebudować świat i zaprowadzić w nim ład.

Książka A. Grześkowiak-Krwawicz napisana jest z perfekcyjną znajomością bogatej w wydarzenia i nowe wizje świata epoki. Autorka przekazuje czytelnikowi swoje spostrzeżenia i głębokie przemyślenia. Przekazuje obraz bardzo wszechstronny, wielowymiarowy, bogaty, bo wsparty na gruntownej znajomości źródeł. Całość napisana jest i przystępnie, i pięknie; bardzo dobrze się książkę czyta. Duże uznanie dla Autorki.

Adam Lityński

4 Cyt. za: P. Hazard, Myśl europejska w XVIII wieku. Od Monteskiusza do Lessinga, przekł. H. Suwała, Wstęp S. Pietraszko, Warszawa 1972, s. 143.

5 Montesquieu, O duchu praw, przekł. T. Boy-Żeleński, przejrzał i uzup. M. Sczaniecki, t. 1, Warszawa 1957, s. 32. 